J. clin. Path. (1948), 1, 232.

\title{
SEROLOGICAL ASPECTS OF WEIL'S DISEASE
}

\author{
BY \\ J. C. BROOM \\ The Wellcome Laboratories of Tropical Medicine, London
}

(RECEIVED FOR PUBlication, MAY 14, 1948)

The agglutination test for Weil's disease (leptospirosis icterohaemorrhagica) is essentially the same as other serological procedures. The disease, however, is comparatively uncommon, and the leptospira suspensions are relatively unstable. For these reasons there has been a tendency for work on leptospirosis to be concentrated in a few laboratories. The observations recorded here are based on the findings in agglutination tests carried out on serum from 219 cases of leptospirosis and from 875 patients suffering from other diseases. Epidemiological and clinical notes on some of these cases have been described by Broom and Alston (1948).

\section{Serological Methods}

Agglutination of formalinized cultures of Leptospira icterohaemorrhagiae was the diagnostic test used in this work. Some workers prefer suspensions of living organisms, but the need to have well-grown, active cultures always available is a disadvantage in routine work, and in our experience the two methods are equally sensitive. Furthermore, with either fresh or inactivated serum, formalinized suspensions agglutinate in the same manner over the whole titre, whereas living cultures lyse in some dilutions of serum, and thereafter present a series of varying agglutination pictures at the different serum-concentrations. In addition, a single strain of leptospira may be lysed by one serum and agglutinated by another in the same dilutions. All these variations are of interest and value for research purposes, but they introduce unnecessary complications for clinical diagnosis.

Antigen.-The same strain of $L$. icterohaemorrhagiae was used throughout, although parallel tests were often carried out with other strains. This strain, " Jackson," was isolated in 1935 from a human case of Weil's disease, and contains both the $A$ and $B$ antigens described by Petersen (1939). Though now com- pletely non-virulent for guinea-pigs, it provides a satisfactory agglutinating suspension.

Stock cultures are maintained in Fletcher's (1927) agar medium and are used to inoculate flasks of Fletcher's broth (in which broth is substituted for agar) or of Korthof's (1932) medium. The cultures are incubated at $26^{\circ} \mathrm{C}$. for five to seven days until they reach a density of about $10^{7}$ leptospirae per $\mathrm{ml}$. In practice, no count is made; the density is judged by examinining a drop of culture by dark-field illumination with a 16-mm. objective and a $\times 10$ ocular. Sufficient formalin is added to give a final concentration of 0.2 per cent ; the suspension is centrifugalized, and any deposit is discarded.

The stability of formalinized suspensions of leptospirae is very variable, and the responsible factors are not yet known. It is our custom, therefore, to prepare quantities of only 50 or $60 \mathrm{ml}$. at one time, and to renew the suspensions at intervals of a few weeks. The suitability of the new suspension is determined by testing the titres of known positive sera in parallel against old and new suspensions. If the new culture differs in agglutinability to an appreciable extent, it is discarded. No attempt has been made to work out a factor for different suspensions, as is done, for example, with standard agglutinating suspensions of the enteric group of bacteria.

Agglutination test.-The technique used is that described by Schüffner and Mochtar (1927). Mixtures of serum and antigen are prepared so that the final dilutions of serum are $1 / 10,1 / 30,1 / 100,1 / 300$, etc., and interaction is allowed to continue overnight at room temperature or at $5^{\circ} \mathrm{C}$. A single drop of each dilution is examined, without a coverglass, by darkground illumination, using a $16-\mathrm{mm}$. objective and a $\times 12.5$ ocular. In our opinion this is the best method of reading the result, because this magnification allows true agglutination in low dilutions $(1 / 10$ and $1 / 30)$ to be distinguished from the non-specific clumping which is produced by a small proportion of sera. In true agglutination, loose floccules of leptospirae are seen 
against a background containing no free organisms, whereas non-specific clumping shows small, compact, refractile masses in which only a proportion of the leptospirae have become entangled, leaving the majority free in the field. For confirmation in doubtful cases the specimen is examined with a $2-\mathrm{mm}$. objective.

\section{Specificity of the Reaction}

Most observers would agree with Smith and Davidson (1936) that "the sero-reaction is entirely specific, agglutinins and lysins being formed as a result of leptospira infection only." These observers found no agglutination in serum dilutions of $1 / 10$ in a series of 403 control tests. Stuart (1946) states that he has " never found antibodies at a titre of $1 / 10$ in people who had not been exposed to known or highly probable leptospiral infection." Ward and Turner (1942), in a survey of workers in different trades, accept a titre of $1 / 10$ as evidence of old infection.

Evidence of a more direct nature is available from the work of Alston and Brown (1935), who tested sera from sewer-workers and found that samples with agglutination titres of $1 / 100$ would protect guinea-pigs against infection with virulent L. icterohaemorrhagiae. The subjects were in normal health when the blood samples were taken, and the agglutination was presumed to be due to residual antibodies from past infection. Similar results were reported by Mason (1938), who obtained partial protection by serum showing a titre of $1 / 30$, and complete protection by sera with titres of $1 / 100$ and 1/300. Our experience of the agglutination test is, in the main, in agreement with these opinions. In this series there were 875 patients where the final diagnosis was not Weil's disease. Of these, nine sera gave agglutination in dilutions up to $1 / 30$, and a further fourteen in a dilution of $1 / 10$ only. Most of these patients worked at occupations where Weil's disease is a recognized hazard, for example on farms, in coal mines, or in sewers, so the possibility of previous contact with leptospirae could not be ruled out.

\section{Para-agglutinins}

Although a positive agglutination test is a specific sign of infection with leptospirae, there is some serological overlap between $L$. icterohaemorrhagiae and the dog leptospira, $L$. canicola, which also is infective to man though only to a minor extent. In most instances the titre of a serum is 10 to 100 times higher for the homologous species, but occasionally, in the early stages of the disease, the titres run parallel, or may even be higher with L. canicola. According to Gispen and Schüffner (1939) this is more likely to happen when the infecting leptospira is of the "incomplete" type of Petersen. An example of this effect is shown in Table I, which sets forth the titres against the two leptospirae of specimens of serum taken on the sixteenth and twenty-sixth days of illness. An earlier specimen, of the eighth day, was negative with both leptospirae. Absorption tests on the sample of the sixteenth day showed the infection to be due to L. icterahaemorrhagiae, but the strain was not isolated to test whether it was of the incomplete type.

\section{Time of Appearance of Antibodies and Titres Reached}

A certain number of observations have previously been made on the interval which elapses between the onset of symptoms and the appearance of demonstrable agglutinins in the serum, and also on the manner in which the antibody titre rises during the course of the disease. In the opinion of Postmus (1933) no positive result is to be expected until after the sixth day; reactions then occur in low dilutions $(1 / 10$ to $1 / 25)$, and

TABLE I

AGGLUTINATION OF L. ICTEROHAEMORRHAGIAE AND L. CANICOLA WITH WEIL'S DISEASE SERUM

\begin{tabular}{|c|c|c|c|c|c|c|c|c|c|c|c|}
\hline & & & & \multicolumn{7}{|c|}{ Dilution of serum } & \multirow{4}{*}{$\begin{array}{l}\text { Serum of } \\
\text { 16th day }\end{array}$} \\
\hline \multirow{2}{*}{\multicolumn{3}{|c|}{ L. icterohaemorrhagiae }} & \multirow{3}{*}{$\begin{array}{l}\cdots \\
.\end{array}$} & $1 / 10$ & $1 / 30$ & $1 / 100$ & $1 / 300$ & $1 / 1000$ & $1 / 3000$ & $1 / 10,000$ & \\
\hline & & & & + & + & + & + & + & \pm & - & \\
\hline L. canicola & $\cdots$ & $\cdots$ & & + & + & + & + & + & + & - & \\
\hline \multicolumn{3}{|c|}{ L. icterohaemorrhagiae } & & + & + & + & + & + & + & - & $\begin{array}{l}\text { Serum of } \\
26 \text { th day }\end{array}$ \\
\hline L. canicola & .. & .. & .. & + & + & \pm & - & - & - & - & \\
\hline
\end{tabular}


TABLE II

RELATION BETWEEN DAY OF DISEASE AND APPEARANCE AND DEVELOPMENT OF ANTIBODIES

\begin{tabular}{|c|c|c|c|c|c|c|c|c|c|}
\hline \multicolumn{10}{|c|}{ Day of disease } \\
\hline 2 & 3 & 4 & 5 & 6 & 7 & 8 & $9-13$ & $14-20$ & $<20$ \\
\hline 0 & $\begin{array}{l}0 \\
0\end{array}$ & $\begin{array}{r}0 \\
30\end{array}$ & $\begin{array}{r}0 \\
0 \\
0 \\
0 \\
30 \\
100 \\
300\end{array}$ & $\begin{array}{r}0 \\
\\
\\
0 \\
0 \\
0 \\
0 \\
10 \\
30 \\
30 \\
30 \\
30 \\
\end{array}$ & $\begin{array}{r}10 \\
\\
\\
\\
\\
\\
\\
\\
0 \\
0 \\
10 \\
30 \\
100 \\
100 \\
300 \\
1,000\end{array}$ & $\begin{array}{r}0 \\
30 \\
30 \\
100 \\
100 \\
100 \\
300 \\
300\end{array}$ & $\begin{array}{r}300 \\
1,000 \\
1,000 \\
1,000 \\
1,000 \\
3,000 \\
\\
300 \\
1,000 \\
100 \\
3,000 \\
1,000 \\
300 \\
1,000\end{array}$ & $\begin{array}{r}3,000 \\
1,000 \\
1,000 \\
300 \\
1,000 \\
3,000 \\
3,000 \\
3,000 \\
3,000 \\
3,000 \\
1,000 \\
3,000 \\
1,000 \\
3,000 \\
100\end{array}$ & $\begin{array}{r}1,000 \\
3,000 \\
\\
1,000 \\
3,000 \\
3,000 \\
10,000 \\
\\
30,000 \\
\\
3,000 \\
10,000 \\
3,000 \\
3,000 \\
3,000 \\
30,000 \\
\\
\\
10,000 \\
\\
300 \\
30,000\end{array}$ \\
\hline
\end{tabular}

$0=$ No agglutination at dilution of $1 / 10.10,30$, etc. $=$ Reciprocals of agglutination titres.

the titre rapidly rises to reach a maximum of $1 / 10,000$ to $1 / 100,000$ by the end of the third week. Kisker (1935) considers that agglutinins are not present before the eighth day, when titres of $1 / 160$ to $1 / 300$ are obtained; thereafter a maximum of $1 / 40,000$ to $1 / 80,000$ is reached between the fifth and seventh weeks. Mochtar and de Reede (1941) also found the agglutination test negative during the first week; the highest titres in their series occurred during the third and fourth weeks.

We have carried out tests at the relevant times on thirty-nine patients, and the results are set out in Table II. The wide variation in the day on which antibodies appear, the rate at which the titre rises, and the maximum reached, is very striking. The earliest positive agglutination was recorded on the fourth day after onset, but negative as well as positive results were obtained on all days up to the eighth, and two sera were still negative on the twelfth and thirteenth days respectively. In some instances, of course, the onset may have been gradual and the stated day may not be quite accurate, but the disease began abruptly in the patient whose serum gave a positive result on the fourth day. 
As will also be seen from the table, there is no apparent correlation, either positive or negative, between the time of first appearance of antibodies and the final titre. On the average, the titres seem to be lower than those often recorded, and we have never found anything approaching, for instance, the $1 / 2,000,000$ reported by Senthille and others (1946). We have tested serum from 169 patients during the third week of illness or later, and the highest titres reached are shown in Table III. Only about 20 per cent rose to $1 / 10,000$, and 7 per cent as low as $1 / 300$.

TABLE III

HIGHEST TITRE OF 169 SERA TESTED DURING THIRD OR LATER WEEK OF DISEASE

\begin{tabular}{c|c|c|c|c|c}
\hline & \multicolumn{5}{|c}{ Reciprocal of titre } \\
\hline & 300 & 1,000 & 3,000 & 10,000 & 30,000 \\
\hline $\begin{array}{l}\text { No. of sera } \\
\text { with titre .. }\end{array}$ & 12 & 47 & 73 & 30 & 7 \\
\hline
\end{tabular}

\section{Effect of Therapeutic Serum}

In some cases the question arises whether the administration of therapeutic serum has vitiated the result of a test. Alston (1940) found that the agglutination became negative in rabbits within three days after the injection of $10 \mathrm{ml}$. of antileptospiral serum per litre of plasma. We tested the result in the human case of influenza, described by Robertson (1946), who received approximately $40 \mathrm{ml}$. of immune horse-serum per litre of plasma. The agglutination titre of the horse serum was $1 / 30,000$, which would give a calculated titre of about $1 / 1,000$ in the general circulation. Samples of blood taken five and sixty minutes after administration showed a titre of $1 / 300$. The level fell to $1 / 100$ after twelve hours, and to $1 / 30$ after twenty-four hours.

\section{Persistence of Antibodies}

It has been shown by a number of workers that antibodies can be demonstrated in the serum many years after recovery from an attack of Weil's disease. Thus Kisker (1935) found positive agglutinations from two to sixteen years after recovery ; Uhlenhuth and Fromme (1930) after twenty-two years ; and Stuart (1939) after twenty-eight years. We have had few opportunities to examine serum after recovery, and the longest interval was four years, but agglutinins were present in all cases. The practical importance of these residual antibodies will be referred to later.

\section{Discussion}

A number of factors must be taken into account when the clinical significance of the results of leptospiral agglutination tests is being assessed. Although in general the test is positive about the end of the first week, there are occasions when the appearance of agglutinins is delayed, as in the two cases cited above which still reacted negatively on the twelfth and thirteenth days respectively. A negative finding may thus merely mean that the blood was examined before antibodies were present. Multiple negative tests throughout the course of illness will exclude Weil's disease with considerable certainty, because it must be very rare to find cases such as that reported by Garnier and Reilly (1917), in which, although leptospirae were isolated from the patient, no antibodies appeared in the blood.

Positive agglutination reactions may be the result of (1) the administration of immune serum ; (2) the presence of residual antibodies from past infection ; (3) present disease.

The giving of serum might affect the result of the test in the early stages, and should be reported by the physician who sends blood for examination.

The possibility of past infection is important in patients who have been in contact directly or indirectly with rats. McKeon and Brown (1936) describe an attack of infective hepatitis in a miner, where the diagnosis was complicated by a positive leptospira agglutination. Three similar cases have occurred in this series. The patients, a farm worker, a seaman, and a refuse collector, all suffered from jaundice. Each case showed a positive agglutination titre of $1 / 100$ or $1 / 300$ but, as there was no increase at subsequent tests, the illness was obviously not Weil's disease.

When the clinical picture is suggestive, the results shown in Table III indicate that a positive agglutination in serum dilutions of $1 / 1,000$ or more may be accepted as confirming the diagnosis. The interpretation of a lower titre is difficult if the findings of only one test are available. As is shown in Table II, titres as low as $1 / 300$ or even $1 / 100$ may occur quite late in the disease. In two of these patients the diagnosis was proved correct by isolating leptospirae from the urine. Low readings cannot therefore be automatically regarded as resulting from past infection. The correct decision can be reached only by repeated examinations.

Early in the disease, say up to the fourteenth day, we would consider positive agglutination even to the lowest titres to be suspicious, and recommend the testing of further specimens. 


\section{Summary}

1. A description is given of the material and methods used in applying the leptospira agglutination test to serum from 219 cases of Weil's disease and 875 of other illnesses.

2. Evidence is put forward confirming the specificity of the test.

3. The shortest interval after the onset of symptoms at which antibodies were detected in the serum was four days. Both positive and negative reactions occurred up to the eighth day; two sera which later became positive were still negative on the twelfth and thirteenth days respectively.

4. Examples are given of the variability of the rate of production of antibodies, and of the highest titre reached in individual patients.

5. In a single experiment samples of serum were tested from a subject who had received $40 \mathrm{ml}$. of antileptospira serum per litre of plasma. From an initial titre of $1 / 300$ at five minutes, the antibodies fell to $1 / 30$ at twenty-four hours.

6. In discussing the clinical interpretation of agglutination tests, stress is laid on the need to consider the result in conjunction with the length of time after infection, and to bear in mind the possibility of previous contact with infection.

7. With suggestive clinical symptoms, an agglu- 등 tination titre of $1 / 1,000$ is considered to confirm the diagnosis. With lower titres and in doubtful cases repeated tests are recommended.

\section{REFERENCES}

Alston, J. M. (1940). Brit. med. J., 2, 256.

Alston, J. M., and Brown, H. C. (1935). Brit. med. J., 2, 339

Broom, J. C., and Alston, J. M. (1948). Lancet, 2, 96.

Fletcher, W. (1927). Trans. roy. Soc. trop. Med. Hyg., 21, 265

Garnier, M., and Reilly, J. (1917). C.R. Soc. Biol. Paris, 80, 101

Gispen, R., and Schüffner, W. (1939). Zbl. Bakt. I. Abt. Orig., 144, 427.

Kisker, A. (1935). Z. Immun. Forsch., 85, 383

Korthof, G. (1932). Zbl. Bakt. I. Abt. Orig., 125, 429.

McKeon, J. A., and Brown, H. C. (1936). Brit. med. J., 2, 174

Mason, W. N. M. (1938). J. Path. Bact. 46, 631.

Mochtar, A., and de Reede, C. A. (1941). Geneesk. Tijdschr. Ned. Ind., 81, 1382 .

Petersen, C. B. (1939). Acta Conventus Tertii de Tropicus Morbis Malariae, Amsterdam, 1938. Part I, p. 396.

Postmus, S. (1933). Nederl. Tijdschr. Geneesk., 77, 2648.
Robertson, K. M. (1946). Brit. med.J., 2, 810.

Schüffner, W., and Mochtar, A. (1927). Zbl. Bakt. I. Abt. Orig., 101, 405.

Senthille, F., de Bayo, P., and Kolochine-Erber, B. (1946). Rer. Path. comp., 46, 161

Smith, J.. and Davidson, L. S. P. (1936). J. Hyg., Camb., 36, 438

Stuart, R. D. (1939). Brit. med. J., 1,324.

Stuart, R. D. (1946). Vet. Rec., 58, 131.

Uhlenhuth, P., and Fromme, W. (1930) in Kolle, W., Kraus, R., and Uhlenhuth, P. "Handbuch der Pathogenen Micro-organismen." Fischer. Jena. 3rd edit., vol. 7, p. 595.

Ward, T. G., and Turner, T. B. (1942). Amer. J. Hyg., 35, 122. 